\title{
Upaya Memperkuat Citra Ramayana Departement Store Melalui Promosi Penjualan dan Periklanan
}

\author{
Didit Darmawan', Rahayu Mardikaningsih², Samsul Arifin³, Mila Hariani4 \\ 1,23,4Fakultas Ekonomi Universitas Mayjen Sungkono Mojokerto \\ Email:dr.diditdarmawan@gmail.com
}

\section{Kata kunci:}

Promosi Penjualan, Iklan, Citra Merk

\section{Keywords:}

sales promotion, advertising, corporate image

Didit Darmawan ${ }^{1}$, Rahayu Mard ikaningsih2, Samsul Arifin ${ }^{3}$, Mila Hariani $^{4}$ (2019). Upaya Memperkuat Citra Ramayana Departement Store Melalui Promosi Penjualan dan Periklanan.

Akuntabilitas: Jurnal Ilmu-Ilmu

Ekonomi, 12(1), 46-57.

https://doi.org/10.35457/akuntabilitas.v1

\begin{abstract}
ABSTRAK
Citra perusahaan yang baik dapat dibentuk melalui komunikasi pemasaran yang tepat pada sasaran. Komunikasi pemasaran terdiri dari beberapa elemen seperti iklan dan promosi penjualan. Dengan promosi penjualan yang menarik yang berbeda dari pesaing serta didukung oleh iklan yang kreatif dan unik yang menggunakan tema yang berbeda untuk menarik minat orang untuk mencoba apa yang ditawarkan perusahaan. Penelitian ini bertujuan untuk menganalisis dan membahas pengaruh promosi penjualan dan iklan terhadap citra perusahaan Ramayana Departement Store. Teknik pengambilan sampel menggunakan metode probability sampling dengan teknik sampel random sampling. Populasi di penelitian ini adalah masyarakat di Kota Surabaya, dengan jumlah sampel 100 responden. Alat analisis yang digunakan adalah regresi linier berganda dengan bantuan SPSS 24.0. Hasil penelitian menunjukkan bahwa promosi penjualan dan iklan memiliki pengaruh secara signifikan dan positif terhadap citra perusahaan.
\end{abstract}

\section{ABSTRACT}

A good corporate image can be formed through marketing communication that is right on target. Marketing communication consists of several elements such as advertising and sales promotions. With attractive sales promotions that are different from competitors and creative and unique advertisements using different themes to attract people's interest and to try what the company offers. This study aims to analyze and discuss the effect of sales promotions and advertisements on the corporate image of the Ramayana Department Store. The sampling technique uses probability sampling method with a sample random sampling technique. The number of samples involved in this study were 100 respondents. Analysis analysis of collected data is processed through multiple linear regression analysis with SPSS 24.0 software. The results state that sales promotions and advertisements have a significant positive effect on corporate image. 


\section{PENDAHULUAN}

Seiring dengan dinamika dan perkembangan di dunia bisnis, semakin meningkat pula persaingan antar perusahaan satu dengan yang lainnya di Indonesia. Di setiap industri saat ini telah terjadi persaingan terbuka dan begitu banyak perusahaan yang berusaha untuk menjadi yang pemimpin pasar yang disertai pula dengan upaya untuk membentuk citra yang positif di masyarakat. Hal ini dipersulit lagi dengan tuntutan untuk beradaptasi terhadap perkembangan teknologi yang menyentuh cara-cara bertransaksi dan hubungan antar penjual dan pembeli.

Industri ritel menjadi salah satu industri yang terus beradaptasi dengan perkembangan teknologi karena pergeseran cara-cara berbelanja yang lebih praktis dari perilaku konsumen. Ramayana departemen store sebagai salah satu contohnya yang masih bertahan setelah sekian lama berada di industri ritel. Ramayana departement store telah memiliki citra perusahaan yang telah terbentuk sekian lama setelah menjadi pelaku di industri ritel dan telah memiliki pangsa pasar yang cukup besar berbagi dengan pelaku lainnya.

Dengan berorientasi pada layanan yang semakin kompetitif, Ramayana departemen store telah mengalami puncak kejayaannya dan saat ini tengah berusaha bertahan untuk tetap menjadi peritel yang dapat berkembang kembali setelah berhasil menyesuaikan diri dengan perubahan sekaligus berusaha mempertahankan bagian dari pangsa pasarnya untuk memperoleh keuntungan jangka panjang. Upaya pencitraan kembali dilakukan dengan meluncurkan beberapa program dari bauran promosi yang salah satunya adalah iklan.

Iklan merupakan termasuk juga strategi yang dapat dilakukan perusahaan untuk memikat hati masyarakat dan untuk mengembangkan citra perusahaan. Dengan iklan yang kreatif dan unik akan dapat menarik minat masyarakat untuk mengunjungi Ramayana departemen store. Iklan kreatif yang dimaksud adalah iklan melalui televisi dan media sosial, dengan menyampaikan kelebihan dan apa saja yang mereka dapatkan dari perusahaan. Harapannya adalah mereka akan beralih dari peritel lain menuju Ramayana. Harapan lainnya adalah mereka yang telah mengenal Ramayana akan lebih sering berbelanja. Iklan yang kreatif dan unik dalam suatu perusahaan akan dapat menimbulkan opini masyarakat terhadap citra perusahaan yang juga dianggap baik oleh masyarakat. Perusahaan 
untuk membuat iklan dapat memakai atau memilih artis top indonesia sebagai salah satu brand ambasador perusahaan, dengan mereka memakai artis top indonesia akan memunculkan opini masyarakat terhadap citra perusahaan yang baik di mata masyarakat. Selain itu mereka dapat juga menggunakan tema yang menarik dan berbeda dengan lainnya sehingga menggugah rasa ingin tahu untuk mengunjungi Ramayana.

Periklanan harus ditujukan pada dasar analisis yang mendalam mengenai situasi pemasaraan saat ini yang terjadi. Iklan menurut Gilson dan Berk (1980) merupakan media komunikasi antar masyarakat dan perusahaan yang sudah dirancang untuk dapat menghasilkan respon dan opini masyarakat untuk membantu tercapainya tujuan pemasaran dari suatu perusahaan. Dunn dan Barban (1996) mengemukakan bahwa komunikasi non pribadi dapat melalui cara yang beragam melalui media sosial yang dibayar oleh perusahaan, dengan iklan yang menarik diharapkan mampu memikat atau membujuk masyarakat yang menbaca iklan tersebut. Indikator iklan ada empat, yaitu (1) dapat menimbulkan perhatian; (2) menarik; (3) dapat menibulkan keinginan; dan (4) menghasilkan suatu tindakan (Wibisono, 2012).

Bukan hanya iklan yang dapat meningkatkan citra perusahaan, promosi penjualan juga mampu menarik pengunjung. Suatu perusahaan yang memiliki citra yang baik akan lebih memudahkan perusahaan tersebut untuk berkembang dengan baik dan bersaing dengan perusahaan yang lainnya. Dalam membangun citra yang baik perusahaan dapat melakukannya dengan promosi penjualan secara besar-besaran kepada masyarakat atau pangsa pasar untuk memperkenalkan jasanya. Perusahaan selalu mencari cara untuk memperoleh efesien dengan mendistribusikan anggaran promosi mereka tetapi banyak perushaan yang telah mengganti cara promosi mereka. Perusahaan melakukan teknik promosi penjualan yang sama dengan pasar domestik lainnya atau mengadakan perubahan dalam promosi untuk tiap pasar lokal. Teknik promosi penjualan yang kreatif akan dapat menarik minat masyarakat sebagai pangsa pasar untuk memajukan perusahaan mereka. Promosi dapat dilakukan melalui televisi, koran maupun brosur, dengan melakukan promosi terus menerus akan menimbulkan ketertarikan masyarakat akan mencoba memakai jasa yang disediakan 
Ramayana departemen store. Promosi penjualan mempunyai manfaat yang berbeda untuk meningkatkan citra perusahaan, manfaat tersebut dapat melalui komunikasi antar perusahaan dan masyarakat menyampaikan jasa yang bersangkutan, insentif juga dapat mendorong kontribusi dan dapat memberikan nilai positif untuk masyarakat, yaitu mendorong terjadinya transaksi pembelian dan perilaku konsumen yang menguntungkan bagi perusahaan.

Perusahaan harus dapat mengalokasikan anggaran mereka untuk melakukan promosi penjualan. Perusahaan perusahaan besar melakukan promosi penjualan untuk menciptakan tanggapan yang positif yang kuat dan cepat. Promosi penjulan menurut Kotler dan Armstrong (2014) sebagai kegiatan yang dilakukan perusahaan untuk memberitahukan manfaat dari menggunakan jasanya untuk meyakinkannya agar menggunakannya. Promosi penjualan yang dilakukan dapat untuk mendapatkan akses yang mudah untuk menjangkau pangsa pasar yang sangat luas. Sedangkan menurut Cumis (1991) sebagai program kegiatan untuk menjalankan target pemasaran yang mengupayakan dengan biaya yang efektif namun menciptakan nilai tambah kepada masyarakat untuk pemakaian jangka panjang. Untuk mengukur pemasaran penjualan dapat diukur melalui lima indikator, (1) frekuensi promosi; (2) kualitas promosi; (3) kuantitas promosi; (4) waktu promosi; dan (5) ketepatan atau kesesuaian sasaran promosi (Kotler dan Keller, 2012).

Suatu perusahaan yang mempunyai citra yang positif dari masyarakat akan menguntungkan bagi perusahaan itu sendiri dalam jangka panjang, karena dengan citra tersebut masyarakat dapat menaruh kepercayaan untuk menggantungkan kebutuhan mereka kepada masyarakat tersebut. Citra menurut Kotler (2002) merupakan persepsi masyarakat terhadap perusahaan tertentu. Nicholas (1992) menyatakan citra perusahaan merupakan gambaran singkat yang melekat pada perusahaan yang dihasilkan mellalui akumulasi pesan-pesan yang sudah diterima masyarakat. Jika citra perusahaan dimata masyarakat buruk akan menurunkan kepercayaan masyarakat terhadap perusahaan tersebut, dan tidak akan menggunakan jasa yang sudah disediakan oleh perusahaan, dan dari masalah tersebut akan dapat merugikan atau menurunkan pendapatan perusahaan. Indikatornya menurut Horrison (1995) adalah (1) kepribadian; (2) reputasi; (3) nilai; dan (4) identitas perusahaan. 
Berdasarkan uraian sebelumnya, penelitian ini bertujuan untuk mengetahui pengaruh promosi penjualan dan kegiatan periklanan terhadap citra perusahaan dari Ramayana Departement Store.

\section{METODE PENELITIAN}

Peneliti menggunakan jenis pendekatan analisis deskriptif kualitatif dengan penelitian eksplanatory research. Metode survei dipilih peneliti digunakan untuk mengumpulkan data yang relatif terbatas dari sejumlah kasus yang relatif besar jumlahnya. Respoden ditetapkan sebanyak 100 orang. Metode pengambilan sampel dengan cara acak. Uji hipotesis melalui uji $\mathrm{t}$ dan uji $\mathrm{F}$ dari bagian regresi linier berganda dengan software SPSS. Syarat yang ditetapkan sebagai responden adalah pengunjung Ramayana Departement Store di kota Surabaya. Tujuan dari survei ini untuk mengetahui bagaimana pendapat responden tentang promosipenjualan dan kegiatan periklanan terhadap citra perusahaan Ramayana departemen store. Berikut adalah variabel-variabel yang terlibat di penelitian ini yang terdiri dari variabel bebas berjumlah dua dan variabel terikat berjumlah satu.

Promosi penjualan atau X1 merupakan sekumpulan alat dan metode untuk mendorong penjualan produk yang ditawarkan perusahaan. Indikator dari variabel promosi penjualan adalah (1) frekuensi promosi; (2) kualitas promosi; (3) kuantitas promosi; (4) waktu promosi; dan (5) ketepatan atau kesuaian sasaran promosi.

Periklanan atau X2 merupakan rancangan media komunikasi perusahaan untuk menarik minat masyarakat untuk menggunakan jasa yang disediakan. Indikator dari variabel Iklan adalah (1) dapat menimbulkan perhatian; (2) menarik; (3) dapat menibulkan keinginan; (4) menghasilkan suatu tindakan.

Citra perusahaan atau $\mathrm{Y}$ adalah gambaran positif yang didapat melalui opini masyarakat terhadap perusahaan. Indikatornya adalah (1) kepribadian; reputasi; (3) nilai; (4) identitas perusahaan.

Pengumpulan data melalui kuesioner yang menggunakan skala Likert's. Kuesioner yang disusun mengikuti model skala likert's penentuan skornya adalah dari "Sangat Setuju Sekali" yang bernilai lima poin hingga "Sangat Tidak Setuju" yang bernilai satu poin. 
Untuk mendukung kualitas data dilakukan uji validitas, reliabilitas, dan uji normalitas. Model dari regresi linier berganda yang baik adalah yang memenuhi setidaknya tiga syarat tersebut. Analisis regresi berganda di penelitian ini memiliki formulasi sebagai berikut :

Dimana:

$$
Y=a+B X_{1}+B X_{2}+e
$$

$\begin{array}{ll}\mathbf{Y} & =\text { Variabel citra perusahaan } \\ \mathbf{a} & =\text { Konstanta } \\ \mathbf{b} & =\text { Koefisien regresi parsial } \\ \mathbf{X}_{1} & =\text { Variabel promosi penjualan } \\ \mathbf{X}_{2} & =\text { Variabel iklan } \\ \mathbf{e} & =\text { Kesalahan pengganggu }\end{array}$

\section{HASIL DAN PEMBAHASAN}

Analisa hasil penelitian dimulai dengan memeriksa skala pengukuran. Pada penelitian ini digunakan analisis regresi melalui program SPSS 24. Pada metode analisis data ini, penulis mencoba beberapa uji seperti yang telah disebutkan sebelumnya. Berdasarkan hasil perhitungan dengan menggunakan SPSS diperoleh hasil seperti pada Tabel 1.

Tabel 1.

Uji Reliabilitas

\begin{tabular}{cccc}
\hline Variabel & N of item & Cronbanch's Alpha & Cut of Value \\
\hline Promosi Penjualan (X1) & 10 & 0.820 & 0.60 \\
\hline Iklan (X2) & 8 & 0.767 & 0.60 \\
\hline Citra Perusahaan (Y) & 8 & 0.743 & 0.60 \\
\hline
\end{tabular}

Sumber: output SPSS

Dari uji reliabilitas promosi penjualan (X1) diperolej nilai 0.820 dari sepuluh pernyataan yang valid. Variabel periklanan (X2) memiliki nilai 0.767 dari delapan pernyataan yang valid. Citra perusahaan $(\mathrm{Y})$ bernilai 0.743 dengan delapan pernyataan dinyatakan reliabel dan valid. Selanjutnya adalah pengujian hipotesis penelitian. Uji selanjutnya adalah uji normalitas seperti ditunjukkan pada Gambar 1 berikut ini.

\section{Gambar 1}


Normal Probability Plot

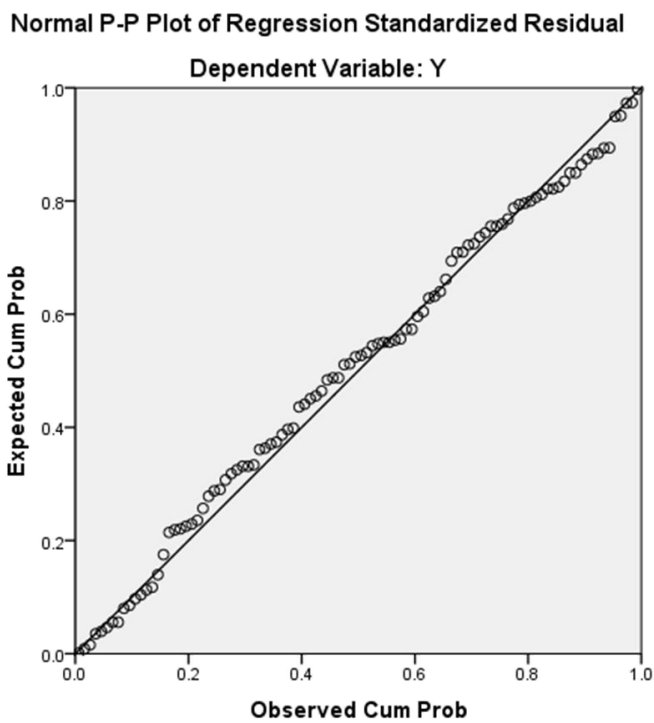

Sumber data: output SPSS

Gambar 1 membuktikan distribusi telah normal. Hal ini karena garis diagonal di sekitarnya terdapat poin yang berdekatan. Poin tersebut bersanding dengan garis lurus diagonal. Inilah yang menunjukkan distribusi data telah normal.

Uji asumsi klasik yang selanjutnya adalah uji autokorelasi dengan berpedoman pada nilai Durbin Watson. Berdasarkan output SPSS menunjukkan tidak ada masalah autokorelasi karena nilai Durbin Watson menunjukkan angka 1.991 yang berarti berada di kisaran nilai 2 dan -2. Dengan demikian tidak ada masalah autokorelasi.

Uji selanjutnya adalah uji heteroskedastisitas. Gambar 2 menunjukkan bahwa titik-titik pada scatterplot tersebar dan berada pada masing-masing bagian di sumbu Y. hal ini membuktikan tidak terjadi heteroskedastisitas 


\section{Gambar 2.}

Scatterplot Dependent Variable

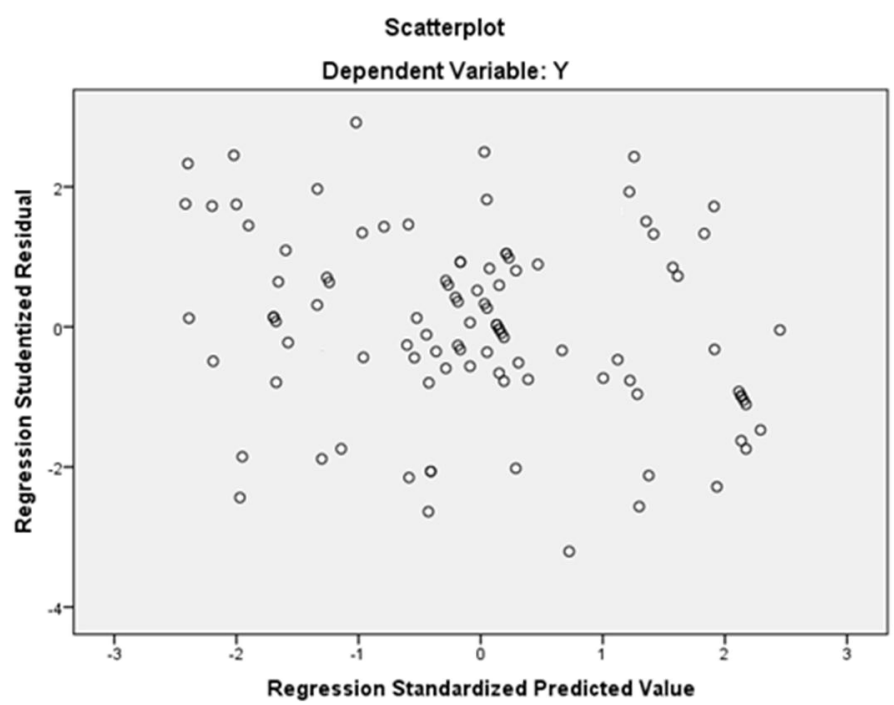

Sumber : Output SPSS

Setelah tiga bentuk dari uji asumsi klasik dilakukan maka selanjutnya dilakukan uji hipotesis melalui dua bentuk pengujian yaitu uji $\mathrm{F}$ dan uji $\mathrm{t}$. Berdasarkan hasil perhitungan dengan menggunakan program SPSS diperoleh hasil seperti pada Tabel 2 berikut ini.

Dari Tabel 2 dapat dilihat bahwa setiap variabel bebas (promosi perijualan dan periklanan) memiliki pengaruh signifikan terhadap variabel terikat (citra perusahaan) secara parsial. Dari hasil perhitungan Tabel 3 maka persamaan regresi yang dihasilkan adalah $\mathrm{Y}=2.131+0.383(\mathrm{X} 1)+0.477(\mathrm{X} 2)$.

\section{Tabel 2.}

t test

\begin{tabular}{|c|c|c|c|c|c|c|}
\hline \multirow{2}{*}{\multicolumn{2}{|c|}{ Model }} & \multicolumn{2}{|c|}{$\begin{array}{c}\text { Unstandardized } \\
\text { Coefficients }\end{array}$} & \multirow{2}{*}{$\begin{array}{c}\text { Standardized } \\
\text { Coefficients }\end{array}$} & \multirow[t]{2}{*}{$t$} & \multirow[t]{2}{*}{ Sig. } \\
\hline & & B & $\begin{array}{l}\text { Std. } \\
\text { Error }\end{array}$ & & & \\
\hline \multirow[t]{3}{*}{1} & (Constant) & 2.131 & 1.630 & & 1.307 & .194 \\
\hline & X1 & .383 & .051 & .464 & 7.513 & .000 \\
\hline & $\mathrm{X} 2$ & .477 & .057 & .521 & 8.425 & .000 \\
\hline
\end{tabular}

Sumber: output SPSS 
Hasil perhitungan Tabel 2 model persamaan regresi linier berganda sebelumnya menunjukkan pengaruh promosi penjualan $(X 1)$ dan periklanan $(X 2)$ secara parsial terhadap citra perusahaan $(\mathrm{Y})$ sebagai variabel terikat. Uji $\mathrm{t}$ membuktikan kebenaran hipotesis tersebut.

Tabel 3.

F test

\begin{tabular}{llrrrrr}
\hline Model & & $\begin{array}{c}\text { Sum of } \\
\text { Squares }\end{array}$ & df & \multicolumn{1}{c}{$\begin{array}{c}\text { Mean } \\
\text { Square }\end{array}$} & F & Sig. \\
\hline \multirow{2}{*}{1} & Regression & 2300.485 & 2 & 1150.243 & 444.030 & $.000^{\mathrm{b}}$ \\
\cline { 2 - 7 } & Residual & 251.275 & 97 & 2.590 & & \\
\cline { 2 - 7 } & Total & 2551.760 & 99 & & & \\
\hline
\end{tabular}

Sumber: output SPSS

Untuk mengetahui kebermaknaan dari pengaruh secara bersama-sama (simultan) dari variabel bebas terhadap variabel terikat melalui uji F. Uji F ini dilakukan dari hasil perhitungan data pada Tabel 3 dapat dilihat bahwa nilai Fhitung sebesar 444.030 dengan probabilitas sebesar 0.000 , hal ini berarti bahwa pada taraf nyata $\mathrm{a}=0.05$ dapat dikatakan bahwa promosi penjualan dan periklanan bepengaruh signifikan secara simultan terhadap terhadap citra perusahaan Ramayana Departemen Store.

Tabel 4

Model Summary

\begin{tabular}{lrrrrrr}
\hline Model & $\mathrm{R}$ & $\mathrm{R}$ & $\begin{array}{c}\text { Adjusted R } \\
\text { Square }\end{array}$ & \multicolumn{2}{c}{$\begin{array}{c}\text { Std. Error of the } \\
\text { Square }\end{array}$} & \multicolumn{2}{c}{ Dstimate } \\
& \multicolumn{2}{c}{ Estin-Watson } \\
\hline 1 & $.949^{\mathrm{a}}$ & .902 & .899 & 1.609 & 1.991
\end{tabular}

Sumber: output SPSS

Berdasarkan pada hasil penghitungan Tabel 4 koefisien R sebesar 0.949. Hal ini berarti hubungan antara variabel adalah sangat kuat. Koefisien determinan $\left(R^{2}\right)$ sebesar 0.902 dan adjusted $R$ squared sebesar 0.899 menunjukkan bahwa model regresi berganda ini yang variabel bebasnya terdiri dari promosi penjualan (X1) dan iklan (X2) telah memberikan kontribusi sebesar 90.2\% terhadap pembentukan variabel terikat yaitu citra perusahaan Ramayana 

lain.

Hasil penelitian ini menyebutkan bahwa promosi penjualan berpengaruh signifikan terhadap citra perusahaan. Hasil ini mendukung temuan dari Hasangholipour et al. (2014) yang menemukan hal yang serupa. Promosi yang dilakukan ini lebih cenderung untuk membentuk sebuah pencitraan dari perusahaan Ramayana departemen store terhadap produk-produk yang ditawarkan dan layanana yang diberikan kepada pelanggannya. Hal ini juga dibuktikan dari hasil penelitian sebelumnya dari Kim dan Hyum (2010) yang menyatakan paket dari bauran pemasaran termasuk promosi telah memberikan kontribusi terhadap citra perusahaan. Upaya dari perusahaan ritel seperti Ramayana, pembentukan citra perusahaan dapat dilakukan dengan iklan atapun promosi melalui televisi, brosur dengan mencantumkan potongan harga dan diskon yang berlaku saat berbelanja dengan minimal jumlah harga tertentu. Dengan mengetahui hal itu, masyarakat sebagai target pasar diharapkan akan bersedia untuk mengunjungi toko ritel dan berbelanja di sana. Dampak yang mungkin juga bisa diharapkan dari kunjungan tersebut adalah kunjungan ulang bahkan kesetiaan terhadap peritel dan tidak akan berpindah ke pesaing lainnya. Jika hal ini terus dilakukan maka secara berlahan secara tidak langsung akan mendorong citra positif perusahaan yang berkembang di masyarakat untuk selanjutnya mendorong tingkat penjualan pada perusahaan Ramayana departemen store. Implikasinya adalah pihak manajemen perusahaan Ramayana departemen store harus memastikan penerapan dari promosi penjualan dan iklan seperti konsistensi harga yang dipromosikan dengan harga yang tertera di label pada produk. Mereka dapat mengatur kembali sistem input dan display pada promosi penjualan termasuk pada harga. Karena biasanya promosi harga di rak display dengan database kasir berbeda dan juga untuk menjual produknya jauh sebelum mendekati tanggal kadaluwarsanya sehingga masyarakat yang merencanakan untuk membeli suatu produk yang dipromosikan di Ramayana tidak mengalami kekecewaan dan penyesalan, jika hal ini terjadi akan dapat memengaruhi citra perusahaan. 
Temuan lain di penelitian ini adalah kegiatan periklanan terbukti memiliki pengaruh terhadap citra perusahaan dan signifikan. Hasil ini serupa dengan temuan Adejumo et al. (2014). Kegiatan periklanan mampu mengembangkan citra perusahaan. Hal ini dikarenakan perusahaan berani menggunakan tema yang menarik dan berbeda untuk mempromosikan dirinya sebagai peritel dengan produk yang berkualitas dan layanan yang prima. Menurut Kellner (1995), perusahaan dapat membuat iklan yang unik dan berbeda dari para pesaing lainnya dan juga berani memakai selebriti indoneisa untuk menjadi brand ambasador mereka. Hal ini karena secara tidak langsung dengan iklan yang unik dan baik akan mempengaruhi perasaan serta emosi mereka dan dengan tidak disadari akan mendorong inisiatif masyarakat sebagai konsumen untuk membeli produk dan merasakan jasanya serta mengarah pada citra perusahaan yang lebih baik. Implikasinya adalah hendaknya pihak manajemen perusahaan Ramayana tetap terus menggunakan tema iklan yang menarik dan berbeda sehingga pesan-pesan komersial yang ingin ditanamkan di benak masyarakat sebagai target pasar berhasil dilakukan dan diingat oleh mereka. Selain itu di kemudian hari, Ramayana dapat melibatkan endorser. Dengan melakukan penempatan pubic figure seperti dari kalangan selebritis sebagai endoser akan memperkuat pesan yang ingin disampaikan selama endorser mempunyai kriteria dan pengalaman menjadi brand ambasador dan memiliki kepribadian yang tidak memicu kontroversi di masyarakat. Kriteria tersebut seperti berpenampilan menarik, terampil, memiliki citra yang baik, dan yang terpenting selebriti itu harus pandai untuk menarik perhatian masyarakat serta untuk menarik minat masyarakat menggunakan dan membeli merek yang ditawarkan dan dapat meningkatkan citra perusahaan.

\section{KESIMPULAN}

Berdasarkan analisis data dan pembahasan ditemukan bahwa promosi penjualan mempunyai pengaruh yang signifikan terhadap citra perusahaan. Selain itu hasil lain membuktikan periklanan mempunyai pengaruh signifikan terhadap citra perusahaan. Berdasarkan uji F, variabel promosi penjualan dan iklan memiliki pengaruh signifikan secara simultan terhadap citra perusahaan. Upaya Memperkuat Citra Ramayana Departement Store Melalui Promosi Penjualan dan Periklanan https:// doi.org/10.35457/akuntabilitas.v12i1.720 
yaitu menciptakan promosi penjualan yang kreatif dan unik serta memperbaiki sistem input dan display dari promosi harga yang tertera agar tidak mengecewakan konsumen yang sudah membeli produk dari perusahaan. Kedua yang dapat dilakukan yaitu menciptakan iklan yang memabngun dan menarik minat masyarakat dengan memilih selebriti yang pandai dan mempunyai citra yang baik untuk menjadi brand ambasador dari perusahaan karena dengan begitu presepsi masyarakat terhadap citra perusahaan akan meningkat seiring dengan iklan-iklan yang sudah disediakan.

\section{DAFTAR PUSTAKA}

Adejumo. D. A., Ogungbade. D. R. \& Akinbode. J. O. 2014. “The Effect of Advertising on Corporate Image: a Study of International Breweries Plc. Ilesa, Osun State, Nigeria". Journal of Marketing Consumer Research. Vol.5. Pp.31-36

Cumis, Julian. 1991. Promosi Penjualan. Terjemahan Oleh Ir. Heryanto, D. MBA. Jakarta: Binarupa Aksara

Dunn, S. W. Dan Barban. 1996. Advertising: it's Role in Modern Marketing. Chicago: Dryden.

Gilson, Christoper \& Berkman, Harold. 1980. Advertising: Consepts and Strategies. New York: Random House, Inc.

Harrison, Shirley. 1995. Marketers Guide to Public Relations. New york: John Willy and Son.

Hasangholipour, Tahmoures., Mohammad, Reza, Mostaghim \& Nazli, Mohammadi, Ahranjani. 2014. "Investigating the Effect of Marketing Mix and Corporate Image on Brand Equity of Thalia and Ridhtel Companies". International Business and Management. Vol.9, No.2, Pp.41-52

Kim, J. \& Hyum, Y. 2010. “A Model to Investigate the Influence of Marketing-Mix Efforts and Corporate Image on Brand Equity in the IT Software Sector". Industrial Marketing Management. Vol.40, Pp.424-438

Kellner, Douglas. 1995. Media Culture: Cultural Studies, and Politics Between the Modern and the Postmodern. London \& New York: Routledge.

Kotler, Philip. 2002. Manajemen Pemasaran. Edisi Melenium. Jilid 2. Jakarta. PT. Prenhallindo. 
Kotler, Philip. \& Gary Armstrong. 2014. Principle Of Marketing, 15th edition. New Jersey: Pearson Prentice Hall.

Kotler Philip \& Kevin Lane Keller. 2012. Marketing Management, 14 th. ed, Pearson Education, Inc., New Jersey.

Loudon, David L \& Albert J. Della Bitta. 2004. Consumer Behavior Concepts and Appications. Third Edition Singapore, MC Graw Hill Inc.

Wibisono, D. 2012. How to Create a World Class Company. Bandung: Penerbit. Erlangga. 